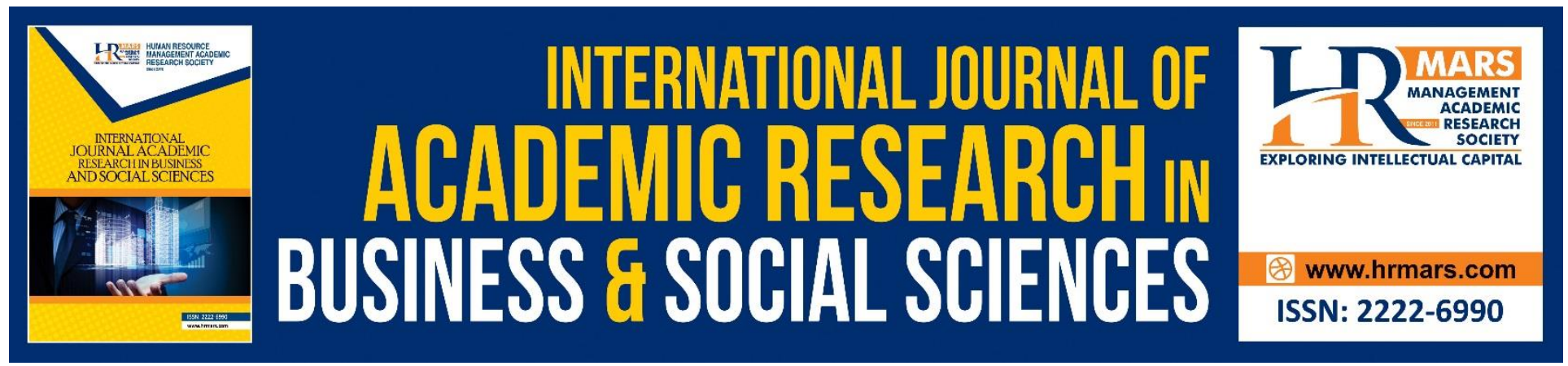

\title{
Air Pollution among 13-Selected Countries: Is it a Major Concern?
}

Siti Ayu Jalil, Gurmit Kaur Bariam Singh

To Link this Article: http://dx.doi.org/10.6007/IJARBSS/v9-i3/5708 $\quad$ DOI: $10.6007 /$ IJARBSS/v9-i3/5708

Received: 18 Feb 2019, Revised: 29 March 2019, Accepted: 09 April 2019

Published Online: 13 April 2019

In-Text Citation: (Jalil \& Singh, 2019)

To Cite this Article: Jalil, S. A., \& Singh, G. K. B. (2019). Air Pollution among 13-Selected Countries: Is it a Major Concern? International Journal of Academic Research in Business and Social Sciences, 9(3), 487-498.

\section{Copyright: (C) 2019 The Author(s)}

Published by Human Resource Management Academic Research Society (www.hrmars.com)

This article is published under the Creative Commons Attribution (CC BY 4.0) license. Anyone may reproduce, distribute, translate and create derivative works of this article (for both commercial and non-commercial purposes), subject to full attribution to the original publication and authors. The full terms of this license may be seen

at: http://creativecommons.org/licences/by/4.0/legalcode

Vol. 9, No. 3, 2019, Pg. 487 - 498

http://hrmars.com/index.php/pages/detail/IJARBSS

JOURNAL HOMEPAGE

Full Terms \& Conditions of access and use can be found at http://hrmars.com/index.php/pages/detail/publication-ethics 


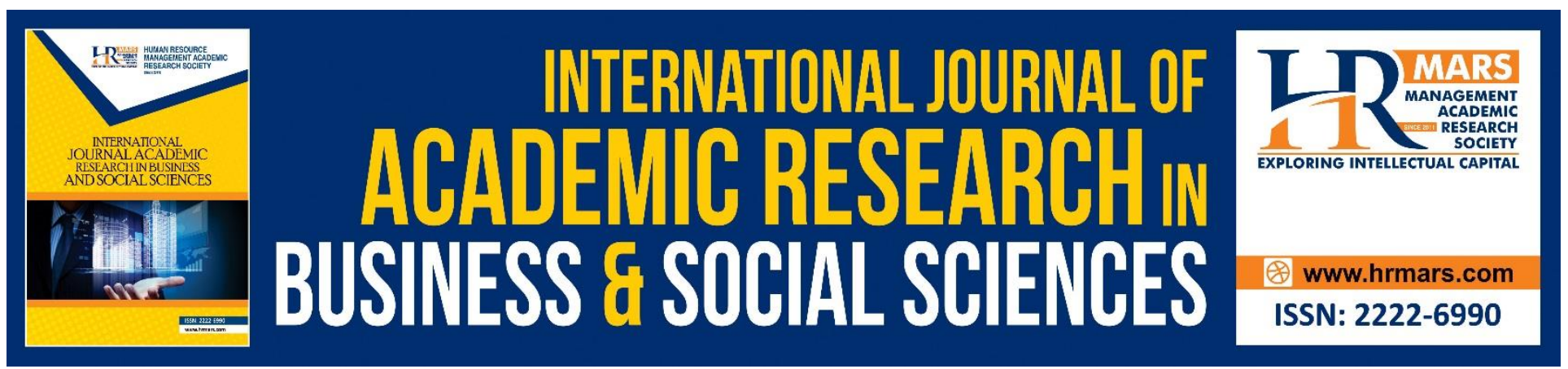

\title{
Air Pollution among 13-Selected Countries: Is it a Major Concern?
}

\author{
Siti Ayu Jalil, Gurmit Kaur Bariam Singh \\ Faculty of Business and Management, UiTM Cawangan Selangor, Kampus Puncak Alam 42300 \\ Bandar Puncak Alam, Selangor, Malaysia
}

\begin{abstract}
This paper studies the scenario of air pollution among selected thirteen countries for a five-year period 2010 until 2014. The countries' main macroeconomics variables namely Gross Domestic Product per capita (GDP), Energy Usage, Urbanization and Industrial Production are the potential causes that could have serious impact on the amount of air pollution among these nations. Three key econometric models using longitudinal data are chosen for analysis i.e. the Pooled Ordinary Least Square (OLS), the Random Effect and Fixed Effect Models. The findings showed that the Pooled OLS explanatory variables are all significant, but only two variables were significant in each random and fixed effects model. However, the appropriate technique that best explain this analysis is the Fixed Effect Model. GDP was the key variable that caused the high emissions of air pollution in these selected countries.
\end{abstract}

Keywords: GDP, Energy Usage, Urbanization, Industrial Production, Panel Data

\section{Introduction}

According to the World Health Organization (WHO) report 2016, air pollution is a situation where indoor and outdoor environment being contaminated by any chemical, physical or even biological agent that modifies the natural characteristics of the air. Air pollution known to have trans-boundary character has become the top global priority as several areas around the world have an average concentration of $\mathrm{PM}_{2.5}$ that is above the air quality guidelines recommended by WHO. $\mathrm{PM}_{2.5}$ refers to the average level of exposure of a nation's population in both urban and rural areas to particles measuring less than 2.5 microns in aerodynamic diameter, of which are capable of penetrating deep into the respiratory tract and causing severe health damage. The high level of concentration has an adverse effect on climate, human health and agriculture due to the greenhouse effect that causes global warming, extreme weather conditions affecting economic activities and depleting of ozone layer. While the direct exposure to air pollutants on the other hand results in heart disease morbidity, premature deaths and reduction in life expectancy. These losses can be further extended to the healthcare or welfare cost and productivity. 
Air pollution is envisaged to be highly linked with economic growth, energy usage, population, industrialization and urbanization (Ehrlich \& Holdren, 1971). Many countries specifically Asia nations are facing the challenges to reduce air pollution and at the same time needs to meet economic development in order to have better standard of living. The process of achieving a high economic growth through focusing on industrial sector, they are much relying on fossil to provide energy for production. Air pollution for these countries has become synonymous with economic growth. Besides that, there is an upward trend showing in the emission of $\mathrm{PM}_{2.5}$ type of air pollution in these nations. On the other hand, population growth and urbanization have a negative effect on the environment as there is threshold for pollution, above a certain environment as there is threshold for pollution, above a certain level the environment is unable to sustain, and the system breaks down. Given that air pollution is a serious threat on natural environment and human life, researchers are giving ever greater importance to the causes of air pollution.

Most studies used the IPAT model which was developed in the 70's to study the effect of human on environment. The letters $(I)$ refer to environmental factor and the human factors are population $(P)$ affluence level (A) and Technology (T) (Ehrlich \& Holdren, 1971). Another model used to study the environmental impact is the environmental Kuznets Curve (EKC) that shows the relationship between economic development and deterioration in the environment, however after a certain point the level of environmental degradation reduces with economic growth as proven by the developed countries. Basically, this study aims to analyze the significant relationship between air pollution and selected variables i.e. gross domestic product per capita, energy usage, urbanization and industrial production with respect to the thirteen selected countries that are Bahrain, Brunei, China, Japan, Kuwait, Malaysia, Oman, Qatar, Saudi Arabia, Singapore, South Korea, Thailand and United Arab Emirates.

The utilization of panel data in this study which combines both time series and cross-section is due to its ability to control unobserved individual and or time specific heterogeneity that could be correlated with the explanatory variables (Hausman \& Taylor, 1981). Beside enhances the quality and quantity of data, it increases the precision of parameter estimates, allows to restructure the model temporal effects without aggregation bias, gives more informative data, less collinearity among variables and more efficient (Gujarati, 2003), (Woolridge, 2009) and (Baltagi, 2005). Employing the three econometric formulations i.e. pooled OLS, random Effect and fixed Effect models, the main intention is to observe the model that best described the analysis.

\section{Literature Review}

This section emphasizes on the empirical studies carried out on the relationship between air pollution and GDP, energy usage, urbanization and industrial production.

\section{Air pollution}

Air pollution can be categories by household air pollution and outdoor pollution. For both these two types of pollution the major concern is particulate matter $\mathrm{PM}_{2.5}$ which is hazardous to human health. A review was done by (Xing, Xu, Shi, \& Lian, 2016) on the linkage between $\mathrm{PM}_{2.5}$ and respiratory 
diseases from epidemiological, experimental and mechanism studies in China revealed that $\mathrm{PM}_{2.5}$ causes human respiratory disease. It was found that anthropogenic ambient $\mathrm{PM}_{2.5}$ caused 1255,400 premature deaths in 2010 which was 42\% higher than in 2000 (Xie, Sabel, Lu, Zhu, Kan, Nielsen, \& Wang, 2016). With rapid development and economic activities, a large amount of this particulate matter is being emitted into the air. There are two sources of $\mathrm{PM}_{2.5}$ emission; they are primary source that is from incomplete combustion, automobile emissions, dust and cooking and secondary source from chemical reaction in the atmosphere. The concentration of $\mathrm{PM}_{2.5}$ increases with economic growth, industrialization and urbanization. Guangdong, Chuanglin, Shaojian, and Siao (2016) however, PM2.5 can be reduced at the expense of short-term economic growth and industrialization but not urbanization. $\mathrm{PM}_{2.5}$ is also found to have seasonal characteristics, the level of concentration increases in winter because of stable meteorological condition and minimum precipitation (Ma, Wang, Yu, Jia, \& Hu, 2016). Similar findings were found by Green, Chow, Watson, Dick, \& Inouye (2015) on five western United States for snow-covered days compared to snow free days.

\section{Gross domestic product}

China is the largest economy in Asia with a soaring economy in the past three decades, its gross domestic product (GDP) expanded 140 times during 1978-2012 (National Bureau of Statistics, 2013). However, such soaring economy is accompanied with deterioration of the atmospheric quality. In the first three months of 2013, just like what happened in London in 1952, long-time haze influenced large area of China, which further stimulated the strong demand for improvement of air quality. Jin, Fang, Wen, and Shan (2017) study on Spatio-temporal variation of PM2.5 from 2005 to 2014 indicated a positive relationship between GDP in the eastern province of China and the level of PM2.5. Wang, Zhou, Wang, Feng, and Hubacek (2017) in their study found inverted "u" shaped relationship between GDP and P.M2.5 concentration implying structural economic change contributes to $\mathrm{PM}_{2.5}$ emissions.

\section{Energy usage}

India and China are said to consume two third of world energy between 2000 and 2012. For China it is estimated that the consumption will nearly be the same as the OECD countries in the year 2035. A study done by Wang and Li (2015) revealed that the growth of energy usage was driven by a combination of growth in individual income and slow growth in population whereas in India it was due to increase in population and slow growth of income.

On the reliance of fuel, 3 billion people worldwide use solid fuels including biomass and coal for their household needs (Rehfuess, Mehta \& Pruss-Ustun, 2006) and $80 \%$ of total fuel is used for domestic cooking. This fuel used for cooking are burnt in poorly ventilated environment resulting in exposure to $\mathrm{PM}_{2.5}$. In India $66 \%$ of household use dung or woody biomass and burnt under inefficient condition and are exposed to smoke consisting toxic substance. Households' prefer to use crop straws, firewood and coal chunks in residential stoves rather than liquefied petroleum gas because of the cost and perceived that the food taste better (Mukhopadhyay, Sambandam, Pillarisetti, Mukhopadhyay, Balakrishnan \& Smith, 2012). According to Shen (2015) household air pollution can be reduced significantly when pelletized biofuels, coal briquettes and gas fuels are used instead of biomass burning. Zhang, Worrell, Crijns-Graus, Krol, de Bruine, Geng, and Cofala (2016) study on the 
other hand revealed that even though energy efficiency measures are not cost efficient, but benefits are about two times higher than the cost of energy efficiency measure. As such planning of energy together with air quality can increase economic efficiency in both areas.

\section{Urbanization}

Urban areas are source of job opportunity and better facilities and have been expanding rapidly with respect to socio-economic development however they are also plagued with air pollution. As seen in case of China, where its urbanization has reached to $53.73 \%$ and has experienced some worst air pollution in recent years leading to health issues due to high concentration of $\mathrm{PM}_{2.5}$ (Gehui, Kawamura, Shuncheng, Kinfai, \& Junji, 2006). Wang et al. (2017) in their study, sorted cities into size of urban areas found that there is a positive correlation between $\mathrm{PM}_{2.5}$ and size of urban areas. Timmermans Kranenburg, Manders, Hendriks, Segers, Dammers, and Schaap (2017) further investigated on the source apportionment of $\mathrm{PM}_{2.5}$ in urban areas in Beijing and Shanghai and found that half of the $\mathrm{PM}_{2.5}$ comes from the municipality itself. However, study done by dos Santos, Kerr, Veríssimo, Andrade, de Miranda, Fornaro, and Saldiva (2014) on highly urbanized city in Brazil found that $\mathrm{PM}_{2.5}$ concentration was acceptable due to general circulation and regional shoreline which are favorable to air pollution dispersion.

\section{Industrial production}

Countries with rapid industrial growth are facing industrial pollution which can be categorized as outdoor pollution and a primary point source of environment contamination. Industrial pollution occurs when electricity is generated by fossil fuel burning especially coal. A study done by Guangdong et al. (2016) in China found that among all the three anthropogenic factors: economic growth, industrialization and urbanization, industrialization was the main contributor of $\mathrm{PM}_{2.5}$ concentration in long run and in summers (Timmermans et al., 2017). Wakeel, Yang, Chen, Hayat, Alsaedi, and Ahmad (2017), in their study in India on the economic activities emitting embodied $\mathrm{PM}_{2.5}$ indicated the "Catering Industry" was the major source of $\mathrm{PM}_{2.5}$ as it uses biomass as their primary fuel. In China the cement industry is the key emitter of air pollutant as it emits $14 \%$ of $\mathrm{PM}_{2.5}$ (Zhang et al., 2016).

\section{Methodology}

This study employs the short-panel balanced data for thirteen selected Asian countries with a limited five-year period. Using the three competing econometric formulations namely pooled model, random effect model and fixed effect model for comparative purpose would provide more information, more variability, more robust analysis and efficiency among the changes in the variables over time. The notation for a panel model is shown as:

$y_{i t}=\beta_{1}+\beta x_{i t}+\varepsilon_{i t}$

Where $i=1, \ldots N$ denotes individual economic units and $\mathrm{t}=1, \ldots T$ denotes time periods. The economic model function for this study is:

$\mathrm{APN}=f(\mathrm{GDP}, \mathrm{EUS}, \mathrm{URB}, \mathrm{IND})$ 
Where

$$
\begin{array}{ll}
\text { APN } & =\text { Air Pollution }\left(\mathrm{PM}_{2.5}\right) \\
\text { GDP } & =\text { Gross Domestic Product per Capita (USD) } \\
\text { EUS } & =\text { Energy Usage ( } \mathrm{kg} \text { of oil equivalent per } \$ 1,000) \\
\text { URB } & =\text { Urbanization (annual \%) } \\
\text { IND } & =\text { Industrial Production (USD) }
\end{array}
$$

\section{Econometric modeling and analysis}

This section will discuss the econometric techniques employed to examine the relationship between the macroeconomic variables and air pollution. The first technique is to run the basic pooled OLS model shown by the equation as:

$$
\ln A P N_{i t}=\alpha+\beta_{1} \ln G D P_{i t}+\beta_{2} \ln E U S_{i t}+\beta_{3} \ln U R B_{i t}+\beta_{4} \ln I N D_{i t}+\varepsilon_{i t}
$$

Where: $\beta_{1}, \beta_{2}, \beta_{3}, \beta_{4}>0$.

Of which In is the log of each variable; $i$ refers to the 13 countries and $t$ is the 5 -year period from 2010-2014. The equation shown above uses all variation in the data; and assumed both intercept and slope are the same across units and time.

However, within the context of panel data, there are two kinds of variation i.e. between cross-section units and within time-series units. Between variance refers to the variability across the unit of observations or cross-sectional variations whereas within variance captures how much the overall variance is due to variability within economic units i.e. the time series variations. These variations can be observed with the random and fixed effect models. Basically, both econometric models merely allow heterogeneity or individuality among the countries by allowing them to have its own intercept value, while restricting the slope to be homogenous. To accommodate such heterogeneity, the error term $\varepsilon_{i t}$, is decomposed into two independent components depicted by the equation as:

$\varepsilon_{i t}=\lambda_{i}+\mu_{i t}$

$\lambda_{i}$ is termed as individual specific effect meaning each country may have a unique characteristic such as in this case different factor endowments or culture. On the other hand, $\mu_{i t}$ is a normal error term denoting the remainder disturbance.

Thus, for the random model, the equation would be:

$$
\ln A P N_{i t}=\alpha+\beta_{1} \ln G D P_{i t}+\beta_{2} \ln E U S_{i t}+\beta_{3} \ln U R B_{i t}+\beta_{4} \ln I N D_{i t}+\lambda_{i}+\mu_{i t}
$$

Where $\lambda_{i}$ becomes part of the error term and would be appropriate if observations are representative of a sample rather than the whole population. In this study only thirteen samples of countries 
categorized under upper middle income and high-income nations were chosen out of 48 countries located in Asia. To compute the analysis for random effects, a crucial assumption to ensure consistency is to assume $\mathrm{E}\left(\mathrm{x}_{k i t} \lambda_{i}\right)=0$ for all $k, t, i$ depicting that $\lambda_{i}$ is uncorrelated with $x_{i t}$. It means the individual specific constant terms are randomly distributed across cross-sectional units. In contrast the fixed effect model is called upon when the individual specific effects are assumed to have intercept that may vary across countries. In econometric terms it is when $\operatorname{Cov}\left(\lambda_{i} x_{i t}\right) \neq 0$ or $\lambda_{i}$ is correlated with $x_{i t}$ meaning it relies on the time series variations but is the most flexible in that it allows endogeneity of regressors. The equation is shown as:

$\ln A P N_{i t}=\left(\beta_{0}+\lambda_{i}\right)+\beta_{1} \ln G D P_{i t}+\beta_{2} \ln E U S_{i t}+\beta_{3} \ln U R B_{i t}+\beta_{4} \ln I N D_{i t}+\mu_{i t}$

$\left(\beta_{0}+\lambda_{i}\right)$ means $\lambda$ becomes part of constant but still varies by individual units.

The appropriate test to discriminate between the pooled model and the random effect model is to utilize the Breusch-Pagan Lagrangian Multiplier (BP-LM) test. The hypothesis for the test is:

$H_{0}: \sigma_{\lambda}^{2}=0$ versus $H_{A}: \sigma_{\lambda}^{2}>0$

On one hand, to choose whether the random or fixed effects models provide better analysis, the statistical test would be the Hausman test that based on the hypothesis:

$H_{0}: \operatorname{Cov}\left(\lambda_{i} X_{i t}\right)=0($ Random $)$ versus $H_{A}: \operatorname{Cov}\left(\lambda_{i} X_{i t}\right) \neq 0($ Fixed $)$

Rejection of the null hypothesis would mean the fixed effect model is the appropriate method to explain the analysis.

A robustness check is also performed to the appropriate model to investigate the structural validity of the analysis. The coefficient covariance method chosen is the White test.

\section{Data sources and definition of variables}

Data of the variables were collected from one source which is the World Development Index (WDI) 2017 for 13 countries from 2010 to 2014. The gross domestic product (GDP) per capita data in constant 2010 U.S. dollars is collected from World Bank national accounts data, and OECD National Accounts data files compiled by WDI. Energy use per PPP GDP is the kilogram of oil equivalent of energy use per constant PPP GDP. It is based on the International Energy Agency (IEA) 2014 data.

Data for urban population in annual percentage growth refers to people living in urban areas as defined by national statistical offices that are collected and smoothed by United Nations Population Division. Data on industrial production is calculated in constant 2010 U.S. dollars collected as well from World Bank national accounts data, and OECD National Accounts data files. Finally, data on air pollution $\mathrm{PM}_{2.5}$ is compiled by Braeur et al., (2016) is defined as the average level of exposure of a 
INTERNATIONAL JOURNAL OF ACADEMIC RESEARCH IN BUSINESS AND SOCIAL SCIENCES

Vol. 9, No. 3, March, 2019, E-ISSN: 222 2-6990 @ 2019 HRMARS

nation's population in both urban and rural areas to particles measuring less than 2.5 microns in aerodynamic diameter, which are capable of penetrating deep into the respiratory tract and causing severe health damage.

\section{Results and Discussion}

The findings begin with a descriptive analysis of each variable as presented in Table 1. Basically, the table displays the characteristics of each series of variables in terms of their means and standard deviation. In summary, the data reveals a reasonable goodness-fit measure based on their skewness of the series which is close to zero but data for air pollution, gross domestic product and urbanization stated a negative value each. On the other hand, the height of the distribution relative to a normal distribution measured by Kurtosis depicts a normal distribution since the values of the series have a uniform distribution of about 3.

Table 1: Descriptive statistics

\begin{tabular}{llllll}
\hline & InAPN & InGDP & InEUS & InURB & InIND \\
\hline Mean & 3.6115 & 10.0236 & 4.9415 & 0.9392 & 25.633 \\
Median & 4.0200 & 10.0525 & 4.8676 & 1.0771 & 25.598 \\
Std. deviation & 0.9309 & 0.79273 & 0.2332 & 0.8259 & 1.6172 \\
Skewness & -0.383 & -0.6378 & 0.7830 & -0.499 & 0.2493 \\
Kurtosis & 2.0134 & 2.3660 & 3.3307 & 2.5972 & 2.6821 \\
Jarque-Bera & 4.2245 & 5.4967 & 6.9378 & 3.1393 & 0.9469 \\
Probability & 0.1210 & 0.0640 & 0.0312 & 0.2081 & 0.6229 \\
\hline
\end{tabular}

To ensure that the variables are not highly correlated among each other, a correlation analysis was carried out and the results are shown in Table 2. Generally, the table shows that the variables are not highly correlated among each other. The highest value of the correlation stated only 0.5796 which is rather low between air pollution and urbanization.

Table 2: Correlation

\begin{tabular}{lccccc}
\hline & InAPN & InGDP & \multicolumn{1}{l}{ InEUS } & \multicolumn{1}{l}{ InURB } & \multicolumn{1}{l}{ InIND } \\
\hline InAPN & 1.0000 & 0.0545 & 0.4850 & 0.5796 & 0.1451 \\
InGDP & 0.0545 & 1.0000 & -0.3561 & -0.0766 & -0.2610 \\
InEUS & 0.4850 & -0.3561 & 1.0000 & 0.1699 & -0.0568 \\
InURB & 0.5796 & -0.0766 & 0.1699 & 1.0000 & -0.2810 \\
InIND & 0.1451 & -0.2610 & -0.0568 & -0.2810 & 1.0000 \\
\hline
\end{tabular}

The analysis starts by running the pooled OLS, then the random effect model followed by fixed effect model. For model specification test, the Breusch Pagan LM test and Hausman test were computed to examine the most appropriate model for the study. The summary of results of each model is depicted in Tables 3 and 4 respectively. 
The results of pooled OLS show all coefficients have positive significant relationship at $1 \%$ level of significance. In contrast with the random and fixed effects models, only two of the explanatory variables were significant. Random effect model reveals GDP and urbanization have positive relationships significant at $1 \%$ and $5 \%$ level of significance, respectively. Whereas fixed effect model portrays GDP to have positive relationship and industrial production to have negative relationship but were significant at $1 \%$ level of significance.

Table 3: Summary of Results

\begin{tabular}{lccc}
\hline & $\begin{array}{c}\text { Pooled } \\
\text { OLS }\end{array}$ & $\begin{array}{c}\text { Random } \\
\text { Effect }\end{array}$ & Fixed Effect \\
\hline Constant & $-19.8819^{* * *}$ & 0.6136 & $7.1398^{* * *}$ \\
InGDP & $0.4972^{* * *}$ & $0.2979^{* * *}$ & $0.8576^{* * *}$ \\
InEUS & $2.2037^{* * *}$ & 0.0928 & 0.1821 \\
InURB & $0.7330^{* * *}$ & $0.0538^{* *}$ & 0.0270 \\
InIND & $0.2704^{* * *}$ & -0.0194 & $-0.5091^{* * *}$ \\
Observation & 65 & 65 & 65 \\
\hline
\end{tabular}

Note: $* * * 1 \%$ level of significance; $* * 5 \%$ level of significance

Table 4: Statistical tests among the Models

\begin{tabular}{lccc}
\hline & $\begin{array}{c}\text { Pooled OLS } \\
\text { versus Random } \\
\text { Effect }\end{array}$ & $\begin{array}{c}\text { Random Effect } \\
\text { versus Fixed } \\
\text { Effect }\end{array}$ & Selection \\
\hline $\begin{array}{l}\text { Breusch and Pagan LM } \\
\text { Test } \\
\text { Hausman Test }\end{array}$ & $61.6607^{* * *}$ & & Random \\
\hline
\end{tabular}

Note: ${ }^{* *} 1 \%$ level of significance; ${ }^{* *} 5 \%$ level of significance

Table 4 shows the results of the statistical test among the models of which the Lagrangian Multiplier (LM) test is significant at $1 \%$ level of significance; hence rejecting the null hypothesis revealing a strong evidence to retain country specific effects. Due to this, the random effect model was chosen to be appropriate description then the pooled OLS. It also identifies that the country specific effects are a random draw that is uncorrelated with the independent variables and the overall error term. To decide between fixed or random effects, the Hausman test is conducted. Table 4 depicts that the null hypothesis is rejected at $1 \%$ level of significance which means the country specific effects are correlated with the regressors. Thus, the random effects estimator is inconsistent implying that the fixed effects model is the appropriate one. 
INTERNATIONAL JOURNAL OF ACADEMIC RESEARCH IN BUSINESS AND SOCIAL SCIENCES

Vol. 9, No. 3, March, 2019, E-ISSN: 222 2-6990 @ 2019 HRMARS

Table 5: Summary of Results for Robust Estimations

\begin{tabular}{lcccc}
\hline & $\begin{array}{c}\text { Pooled } \\
\text { OLS, } \\
\text { robust }\end{array}$ & $\begin{array}{c}\text { Fixed Effect } \\
\text { Cross } \\
\text { Section }+ \\
\text { Year }\end{array}$ & $\begin{array}{c}\text { Fixed Effect } \\
\text { Cross Section }+ \\
\text { Year Robust }\end{array}$ & $\begin{array}{c}\text { Fixed Effect } \\
\text { Year } \\
\text { Robust }\end{array}$ \\
\hline Constant & $-19.881^{* * *}$ & 7.4297 & 7.4297 & $-19.882^{* * *}$ \\
In GDP & $0.4972^{* * *}$ & $0.8262^{* * *}$ & $0.8262^{* * *}$ & $0.4957^{* * *}$ \\
InEUS & $2.2037^{* * *}$ & 0.1551 & $0.1551^{* *}$ & $2.1928^{* * *}$ \\
InURB & $0.7330^{* * *}$ & 0.0248 & $0.0248^{*}$ & $0.7578^{* * *}$ \\
In IND & $0.2704^{* * *}$ & $-0.5028^{* * *}$ & $-0.5028^{* * *}$ & $0.2721^{* * *}$ \\
Observation & 65 & 65 & 65 & 65 \\
\hline
\end{tabular}

Note: $* * * 1 \%$ level of significance; $* * 5 \%$ level of significance $\& * 10 \%$ level of significance

Since the fixed effects model is the appropriate model for the analysis, a robustness check was performed on the model to examine the structural validity of the analysis. The results shown in Table 5 revealed that GDP proven to be consistent having a significant positive relationship with air pollution even for robust estimations. Similarly, industrial production indicates a negative significant relationship while energy usage and urbanization portray a positive significant relationship at $5 \%$ and $10 \%$ significance level, respectively.

\section{Conclusion}

Rapid economic growth, industrialization and urbanization including higher demand for energy consumption have caused severe air pollution that consequently leads to adverse effects on human health, climate change and even reduction in life expectancy of a nation. This study employed the panel data set structure utilizing the three econometric formulations namely the pooled OLS, Random and Fixed Effects model to examine the factors contributing to the increase in air pollution specifically $\mathrm{PM}_{2.5}$ among the selected thirteen countries from 2010 to 2014 . The results based on the appropriate model i.e. Fixed effect showed that GDP per capita and industrial production are significant of which the former revealed a positive relationship whereas the later a negative relationship. One can conclude that these two factors are the important ones contributing to the increase in air pollution in these countries.

\section{Acknowledgement}

We would like to thank our Dean Faculty of Business and Management for partly sponsoring the conference and publication fees of this study.

\section{Corresponding Author}

Dr Siti Ayu Jalil, Faculty of Business and Management, UiTM Cawangan Selangor, Kampus Puncak Alam 42300 Bandar Puncak Alam, Selangor, Malaysia, ayu090@salam.uitm.edu.my, Institut Pengangkutan Malaysia (MITRANS), Universiti Teknologi MARA, 40450 Shah Alam, Selangor, Malaysia. 
INTERNATIONAL JOURNAL OF ACADEMIC RESEARCH IN BUSINESS AND SOCIAL SCIENCES

Vol. 9, No. 3, March, 2019, E-ISSN: 222 2-6990 @ 2019 HRMARS

\section{References}

Baltagi, B. (2005). Econometric Analysis of panel data. New York, NY: Cambridge University Press.

Brauer, M., Freedman, G., Frostad, J., van Donkelaar, A., Martin, R. V., Dentener, F., ... Cohen, A. (2016). Ambient air pollution exposure estimation for the global burden of disease 2013. Environmental Science and Technology, 50, 79-88. Doi:10.1021/acs.est.5b03709

dos Santos, L. H. M., Kerr, A. A. F. S., Veríssimo, T. G., Andrade, M. d. F., de Miranda, R. M., Fornaro, A., \& Saldiva., P. (2014). Analysis of atmospheric aerosol (PM 2.5 ) in Recife City, Brazil. Journal of the Air and Waste Management Association, 64, 519-528. Doi: 10.1080/10962247.2013.854282

Ehrlich, R. P., \& Holdren, J. P. (1971). Impact of population growth. Science, 171, 1212-1217. URL:http://links.jstor.org/sici?sici=00368075\%2819710326\%293\%3A171\%3A3977\%3C1212\%3AI OPG\%3E2.0.CO\%3B2-E

Gehui, W., Kawamura, K., Shuncheng, L., Kinfai, H., \& Junji, C. (2006). Molecular, seasonal, and spatial distributions of organic aerosols from fourteen Chinese cities. Environmental Science and Technology, 40, 4619-4625. Doi:10.1021/es060291x

Green, M. C., Chow, J. C., Watson, J. G., Dick, K., \& Inouye, D. (2015). Effects of snow cover and atmospheric stability on winter $\mathrm{PM}_{2.5}$ concentrations in Western U.S. Valleys. Journal of Applied Meteorology and Climatology, 54, 1191-1201. Doi: 10.1016/j.rse.2018.12.002

Guangdong, L., Chuanglin, F., Shaojian, W., \& Siao, S. (2016). The effect of economic growth, urbanization, and industrialization on fine particulate matter (PM2.5) concentrations in China. Environmental Science and Technology, 50, 11452-11459. Doi:10.1021/acs.est.6b02562

Gujarati, D. (2003). Basic Econometrics. New York, NY: McGraw Hill.

Hausman, J. A., \& Taylor, W. E. (1981). Panel data and unobservable individual effects. Econometrica, 49, 1377-1398. Doi:10.2307/1911406

Jin, Q., Fang, X., Wen, B., \& Shan., A. (2017). Spatio-temporal variations of PM2.5 emission in China from 2005 to 2014. Chemosphere, 183, 429-436. Doi:10.1016/j.chemosphere.2017.05.133

Ma, X., Wang, J., Yu, F., Jia, H., \& Hu, Y. (2016). Can MODIS AOD be employed to derive PM2.5 in Beijing-Tianjin-Hebei over China? Atmospheric Research, 181, 250-256. Doi:10.1016/j.atmosres.2016.06.018

Mukhopadhyay, R., Sambandam, S., Pillarisetti, A., Jack, D., Mukhopadhyay, K., Balakrishnan, K., \& Smith., K. R. (2012). Cooking practices, air quality, and the acceptability of advanced cookstoves in Haryana, India: An exploratory study to inform large-scale interventions. Global Health Action, 5, 1-13. Doi:10.3402/gha.v5i0.19016.

National Bureau of Statistics, 2013. http://www.stats.gov.cn/english/statisticaldata/AnnualData/

Rehfuess, E., Mehta, S., \& Pruss-Ustun., A. (2006). Assessing household solid fuel use: Multiple implications for the millennium development goals. Environmental Health Perspectives, 114 (3), 373-378. Doi: 10.1289/ehp.8603

Shen, G. (2015). Quantification of emission reduction potentials of primary air pollutants from residential solid fuel combustion by adopting cleaner fuels in China. Journal of Environmental Sciences, 37, 1-7. Doi:10.1016/j.jes.2015.04.018 
Timmermans, R., Kranenburg, R., Manders, A., Hendriks, C., Segers, A., Dammers, E., ... Schaap, M. (2017). Source apportionment of PM2.5 across China using LOTOS-EUROS. Atmospheric Environment, 164, 370-386. Doi:10.1016/j.atmosenv.2017.06.003

Wang, Q., \& Li., R. (2016). Drivers for energy consumption: A comparative analysis of China and India. Renewable and Sustainable Energy Reviews, 62, 954-962. Doi:10.1016/j.rser.2016.04.048

Wang, S., Zhou, C., Wang, Z., Fengand, K., \& Hubacek, K. 2017. The characteristics and drivers of fine particulate matter (PM2.5) distribution in China. Journal of Cleaner Production, 142, 1800-1809. Doi: 10.1016/j.jclepro.2016.11.104

Wakeel, M., Yang, S., Chen, B., Hayat, T., Alsaedi, A., \& Ahmad., B. (2017). Network perspective of embodied PM2.5 - A case study. Journal of Cleaner Production, 142, 3322-3331. Doi:10.1016/j.jclepro.2016.10.138

Wooldridge, J. M. (2009). Introductory Econometrics: A Modern Approach. South-Western, Cengage Learning.

Xie, R., Sabel, C. E., Lu, X., Zhu, W., Kan, H., Nielsen, C. P., \& Wang, H. (2016). Long-term trend and spatial pattern of PM2.5 induced premature mortality in China. Environment International, 97, 180-186. Doi:10.1016/j.envint.2016.09.003

Xing, Y.F., Xu, Y.H., Shi, M.H., \& Y.X.Lian. (2016). The impact of PM2.5 on the human respiratory system. Journal of Thoracic Disease, 8, E69-E74. Doi:10.3978/j.issn.2072-1439.2016.01.19

Zhang, S., Worrell, E., Crijns-GrausKrol, W., de Bruine, M., Geng, M., \& Cofala., J. (2016). Modeling energy efficiency to improve air quality and health effects of China's cement industry. Applied Energy, 184, 574-593. Doi:10.1016/j.apenergy.2016.10.030 